\title{
MODEL PENDEKATAN KONSELING CLIENT CENTERED DAN PENERAPANNYA DALAM PRAKTIK
}

\author{
Ulfa Danni Rosada *) \\ rosada_ulfa@yahoo.co.id
}

\begin{abstract}
Abstrak
Client Centered Theory sering pula dikenal sebagai teori non-direktif atau berpusat pada pribadi. Pendekatan konseling client centered menekankan pada kecakapan klien untuk menentukan isu yang penting bagi dirinya dan pemecahan masalah dirinya. Konsep pokok yang mendasari adalah hal yang menyangkut konsep-konsep mengenai diri (self), aktualisasi diri, teori kepribadian,dan hakekat kecemasan. Peran konselor dalam model pendekatan konseling client centered adalah : (1) Konselor tidak memimpin, mengatur atau menentukan proses perkembangan konseling, tetapi hal tersebut dilakukan oleh klien itu sendiri. (2) Konselor merefleksikan perasaan-perasaan klien, sedangkan arah pembicaraan ditentukan oleh klien. (3) Konselor menerima klien dengan sepenuhnya dalam keadaan seperti apapun. (4) Konselor memberi kebebasan pada klien untuk mengeksperisikan perasaan-perasaan sedalam-dalamnya dan seluas-luasnya.
\end{abstract}

Kata Kunci: Model Pendekatan Konseling, Client Centered, Penerapannya dalam praktik

\begin{abstract}
Client centered theory often also known as a theory nondirektiv or centered in a personal. Counseling client approach centered emphasis on skill clients to determine the issues that are important for himself and the solution of a problem himself. The concept of basic underlying is easy for concepts out of ( self), actual self, the theory personality, and essence anxiety. The role of a counselor in the model approach centered counseling client is: (1) counselor is not leading, set or determine the developmental process counseling, but it has to be done by the clients itself.( 2 ) counselor reflect my emotions clients, while the direction of talks determined by the clients. ( 3 ) counselor receive clients by fully in a state of no matter.( 4 ) counselor gave freedom on the client for mengeksperisikan deepest and my emotions as possible.
\end{abstract}

Keyword: Model approach counseling, client centered, the application in practice

* Ulfa Danni Rosada adalah Dosen Program Studi Bimbingan dan Konseling Fakultas Keguruan dan Ilmu Pendidikan Universitas Ahmad Dahlan Yogyakarta. 


\section{PENDAHULUAN}

Konselor sebagai rebuah
profesi dalam
profesionalnya menggunakan cara-
cara tertentu yang berbeda dengan
profesi lain yang mempunyai tujuan
yang sama, yaitu membantu
penyelesaian masalah konseli.

Keberadaan ditunjukkan pada ragam tindakan konselor dalam membantu konseli dalam bentuk layanan konseling.

Konseling sebagai cara membantu, memiliki bermacammacam model dalam mendekati konseli beserta masalahnya. Kata "mendekati" atau pendekatan menunjuk pada aspek pribadi konseli yang ingin disentuh dan diberdayakan oleh konselor untuk mengatasi masalahnya yang mereka hadapi. Menurut Nelson (2011) model pendekatan konseling dalam judul pendekatannya, misalnya person centered therapy, gestalt therapy, rational emotive behavior therapy, cognitive therapy.

Client Centered Theory sering pula dikenal sebagai teori nondirektiv atau berpusat pada pribadi. Client Centered sebagai model pendekatan dalam konseling merupakan hasil pemikiran Carl Rogers. Rogers adalah seorang empirisme yang mendasarkan teoriteorinya pada data mentah, ia percaya pentingnya pengamatan subyektif, ia percaya bahwa pemikiran yang teliti dan validasi penelitian diperlukan untuk menolak kecurangan diri (self-deception). Yang mana Rogerian tidak hanya berisi pertanyaan-pertanyaan teori tentang kepribadian dan psikoterapi, tetapi juga suatu pendekatan, suatu orientasi atau pandangan tentang kehidupan.

Rogers (dalam Corey 2006: 7)

mengemukakan bahwa:

Dalam konteks konseling, Rogers menemukan dan mengembangkan teknik konseling yang dikenal sebagai Client-centered Therapy, yakni teknik terapi yang berpusat pada klien. Dibandingkan teknik terapi yang ada masa itu, teknik ini adalah pembaharuan karena mengasumsikan posisi yang sejajar antara konselor dan pasien atau klien. Hubungan konselor-klien diwarnai kehangatan, saling percaya, dan klien diberikan diperlakukan sebagai orang dewasa yang dapat mengambil keputusan sendiri dan bertanggungjawab atas keputusannya. Tugas 
konselor adalah membantu klien mengenali masalahnya dirinya sendiri sehingga akhrinya dapat menemukan solusi bagi dirinya sendiri.

Pendekatan konseling client centered menekankan pada kecakapan klien untuk menentukan isu yang penting bagi dirinya dan pemecahan masalah dirinya. Konsep pokok yang mendasari adalah hal yang menyangkut konsep-konsep mengenai diri (self), aktualisasi diri, teori kepribadian, dan hakekat kecemasan. Menurut Roger (dalam Juntika, 2006:21) "konsep inti konseling berpusat pada klien adalah konsep tentang diri dan konsep menjadi diri atau pertumbuhan perwujudan diri".

Inti dari konseling berpusat pada klien ini adalah tentang diri dan konsep menjadi diri atau pertumbuhan perwujudan diri. Dikatakan bahwa konsep atau struktur diri dipandang sebagai konfigurasi persepsi yang terorganisasikan tentang diri yang membawa kesadaran. Hal itu terdiri dari atas unsur-unsur persepsi terhadap karakteristik dan kecakapan seseorang, pengamatan dan konsep diri dalam hubungan dengan orang lain dan lingkungan dan cita-cita yang dipandang mempunyai kekuatan positif dan negatif. Rogers membangun teorinya ini berdasarkan penelitian dan observasi langsung terhadap peristiwa-peristiwa nyata, dimana pada akhirnya ia memandang bahwa manusia pada hakekatnya adalah baik.

Menurut Sayekti (1997), ada beberapa konsepsi Rogers tentang hakekat manusia adalah: (1) Manusia tumbuh melalui pengalamannya, baik melalui perasaan, berfikir, kesadaran ataupun penemuan. (2) Hidup adalah kehidupan saat ini dan lebih dari pada perilaku- perilaku otomatik yang ditentukan oleh kejadiankejadian masa lalu, nilai-nilai kehidupan adalah saat ini dari pada masa lalu, atau yang akan datang. (3) Manusia adalah makhluk subyektif, secara esensial manusia hidup dalam pribadinya sendiri dalam dunia subjektif. (4) Keakraban hubungan manusia merupakan salah satu cara seseorang paling banyak memenuhi kebutuhannya. (5) Pada umumnya setiap manusia memiliki kebutuhankebutuhan untuk bebas, spontan, 
bersama-sama dan saling

berkomunikasi. (6) Manusia

memiliki kecenderungan ke arah aktualisasi, yaitu tendensi yang melekat pada organisme untuk mengembangkan keseluruhan kemampuannya dalam cara memberi pemeliharaan dan mempertinggi aktualisasi diri.

Manusia dalam pandangan Rogers menurut Hidayat (2011) adalah (1) ia memandang manusia terisolasi dan bergerak ke depan, berjuang untuk berfungsi penuh, serta memiliki kebaikan. Manusia pada dasarnya dapat dipercayai, kooperatif, dan konstruktif, tidak perlu melakukan pengendalian terhadap dorongan-dorongan agresif yang dimilikinya. (2) manusia juga memiliki kemampuan menentukan nasibnya sendiri, dapat dipercaya dan mengejar kesempurnaan diri. Asumsinya Rogers tentang manusia adalah bahwa manusia itu bebas, rasional, utuh, mudah berubah, subjektif, proaktif, tetapi heterostatis dan sulit dipahami. (3) Rogers percaya dan optimis dengan sifat alami manusia. Dorongan paling besar pada manusia adalah aktualisasi diri yaitu memelihara, menegakkan, mempertahankan diri dan meningkatkan diri dengan memberikan kesempatan terhadap individu untuk berkembang dalam gerak maju dan memiliki cara untuk menyesuaikan diri

Peran konselor dalam model pendekatan konseling client centered adalah : (1) Konselor tidak memimpin, mengatur atau menentukan proses perkembangan konseling, tetapi hal tersebut dilakukan oleh klien itu sendiri. (2) Konselor merefleksikan perasaanperasaan klien, sedangkan arah pembicaraan ditentukan oleh klien. (3) Konselor menerima klien dengan sepenuhnya dalam keadaan seperti apapun. (4) Konselor memberi kebebasan pada klien untuk mengeksperisikan perasaan-perasaan sedalam-dalamnya dan seluuasluasnya.

\section{PEMBAHASAN}

1. Client centered sebagai Model Pendekatan dalam Konseling

Bertolak dari peran konselor sebagai guru dengan beragam tindakannya dalam memberikan perlakuan terhadap 
siswa, maka Client Centered

sebagai model dalam konseling merupakan pendekatan, deskripsi proses konseling, tujuan konseling, teknik konseling, kelebihan dan keterbatasan serta hasil konseling dan penerapan dalam proses belajar mengajar di sekolah.

I. Client centered sebagai PENDEKATAN, merupakan cara umum dalam memandang permasalahan atau objek kajian.

Asumsi Perilaku Bermasalah menurut Rogers adalah ketika tidak adanya hubungan yang kongruen antara real self dan ideal self-nya serta self as thought to be seen by others.

II. Deskripsi proses konseling dalam model pendekatan Client Centered merupakan suatu gambaran bagaimana proses pendekatan ini dilaksanakan. Adapun deskripsi proses konseling itu adalah : (a) Konseling memusatkan pada pengalaman individual. (b)
Konseling berupaya

meminimalisir rasa diri

terancam, dan memaksimalkan dan serta menopang eksplorasi diri. Perubahan perilaku datang melalui pemanfaatan potensi individu untuk menilai pengalamannya, membuatnya untuk memperjelas dan mendapat tilikan perasaan yang mengarah pada pertumbuhan. (c) Melalui penerimaan terhadap klien, konselor membantu untuk menyatakan, mengkaji dan memadukan pengalamanpengalaman sebelumnya ke dalam konsep diri. (d) Dengan redefinisi, pengalaman, individu mencapai penerimaan diri dan menerima orang lain dan menjadi orang yang berkembang penuh. (e) Wawancara merupakan alat utama dalam konseling untuk menumbuhkan hubungan timbal balik.

III. Client Centered sebagai Tujuan Konseling, ia 
merupakan harapan yang ingin dimiliki setelah proses konseling berlangsung.

Adapun Tujuan Konseling yang hendak dicapai dalam hal ini adalah : (1) Memberi kesempatan dan kebebasan klien untuk mengekspresikan perasaan-perasaannya, berkembang dan terealisir potensinya. (2) Membantu individu untuk sanggup berdiri sendiri dalam mengadakan integrasi dengan lingkungannya, dan bukan pada penyembuhan tingkah laku itu sendiri. (3) Membantu individu dalam mengadakan perubahan dan pertumbuhan.

IV. Teknik

Client centered sebagai teknik, ia merupakan suatu cara yang penekanan masalah ini adalah dalam hal filosofis dan sikap konselor, dan mengutamakan hubungan konseling ketimbang perkataan dan perbuatan konselor. Implementasi teknik konseling didasari oleh paham filsafat dan sikap konselor tersebut. Karena itu teknik konseling Rogers berkisar antara lain pada caracara penerimaan pernyataan dan komunikasi, menghargai orang lain dan memahaminya (klien). Karena itu dalam teknik dapat digunakan sifatsifat konselor berikut:

a. Acceptance artinya konselor menerima klien sebagaimana adanya dengan segala masalahnya. Jadi sikap konselor adalah menerima secara netral.

b. Congruence artinya karakteristik konselor adalah terpadu, sesuai kata dengan perbuatan dan konsisten.

c. Understanding artinya konselor harus dapat secara akurat dan memahami secara empati dunia klien sebagaimana dilihat dari dalam diri klien itu.

d. Non-judgemental artinya tidak memberi penilaian 
terhadap klien, akan tetapi

konselor selalu objektif.

V. Kelebihan dan keterbatasan

Client centered sendiri

merupakan model pendekatan

konseling yang tentunya

memiliki kelebihan serta

keterbatasan.

Adapun

kelebihan dan keterbatasan

itu adalah:

Kelebihan:

a. Pemusatan pada klien dan bukan pada terapis

b. Identifikasi dan

hubungan terapi sebagai

wahana utama dalam

mengubah kepribadian.

c. Lebih menekankan pada sikap terapi daripada teknik.

d. Memberikan

kemungkinan untuk

melakukan penelitian dan

penemuan kuantitatif.

e. Penekanan emosi, perasaan, perasaan dan afektif dalam terapi.

f. Menawarkan perspektif yang lebih up-to-date dan optimis. g. Klien

memiliki

pengalaman positif dalam

terapi ketika mereka

focus dalam

menyelesaiakan

masalahnya.

h. Klien merasa mereka dapat mengekpresikan dirinya secara penuh ketika mereka mendengarkan dan tidak di justifikasi

Keterbatasan

Kurangnya kekonkritan; dalam proses konseling, lebih efektif ketika menggunakan bahasa verbal dan dengan klien yang cerdas; mengabaikan faktor ketidaksadaran (alam tak sadar) dan insting naluri; berurusan dengan hal-hal yang ada di permukaan.

VI. Hasil konseling

Setelah konselor melakukan konseling kepada konselinya, harapan yang ingin diraih oleh seorang konselor yakni hasil konseling. Pada prinsipnya sulit untuk membedakan 
antara proses dengan hasil

konseling. Ketika kita mempelajari hasil secara langsung, maka sebenarnya kita menguji perbedaanperbedaan antara dua perangkat observasi yang dibuat pada awal dan akhir dari rangkaian wawancara. Walau demikian Rogers mengatakan hasil konseling ialah klien menjadi lebih kongruen, lebih terbuka terhadap masalahmasalahnya, kurang defensif, yang senua ini nampak dalam. dimensi-dimensi pribadi dan perilaku.

Berdasarkan hasil riset, beberapa hasil konseling antara lain:

a. Peningkatan dalarn penyesuaian psikologis.

b. Kurangnya keteganggan pisik dan pemikiran kapasitas yang lebih besar untuk merespon rasa frustasi.

c. Menurutnya sikap defensive. d. Tingkat hubungan yang lebih besar antara self picture dengan self ideal.

e. Secara, emosional lebih matang.

f. Peningkatan dalam keseluruhan penyesuaian dalam latihan-latihan vokasional.

g. Lebih kreatif.

VII.Penerapan dalam proses belajar mengajar di sekolah

Filsafat yang mendasari teori client centered memiliki penerapan langsung pasa proses belajar mengajar. Perhatian Rogers pada sifat proses belajar yang dilibatkan dalam konseling juga telah beralih pada perhatian terhadap apa yang terjadi dalam pendidikan. Dalam bukunya yang berjudul Freedom To Learn (1969), Rogers mengupas soal-soal yang mendasar bagi pendidikan humanistik dan mengajukan suatu filsafat bagi kegiatan belajar yang terpusat pada siswa. Pada dasarnya, filsafat pendidikan 
yang diajukan oleh Rogers

sama dengan pendapatnya

tentang konseling dan terapi, yakni : ia yakin bahwa siswa dapat dipercaya untuk menemukan masalah-masalah yang penting yang berkaitan dengan keberadaan dirinya. Para siswa bisa terlibat dalam suatu kegiatan belajar yang bermakna, yang bisa timbul dalam bentuknya yang terbaik jika guru menciptakan iklim kebebasan dan kepercayaan.

Fungsi guru, sama dengan fungsi terapis client centered, yaitu kesejatian, keterbukaan, ketulusan, penerimaan, pengertian, empati dan kesediaan untuk membiarkan para siswa mengeksplorasi material yang bermakna, menciptakan atmosfer dimana kegiatan belajar yang signifikan bisa berjalan.

Rogers menganjurkan pembaharuan pendidikan dan menyatakan bahwa jika ada satu saja diantara seratus orang guru mengajar di ruangan-ruangan kelas yang terpusat pada siswa dimana para siswa diizinkan untuk bebas menekuni persoalanpersoalan yang relevan. Secara singkat dapat dirumuskan bahwa teori Rogers berlandaskan dalil bahwa klien memiliki kesanggupan untuk mengalami faktor-faktor yang ada dalam hidupnya yang menjadi sebab ketidakbahagiaan. Klien juga memiliki kesanggupan untuk mengarahkan diri dan melakukan perubahan pribadi yang konstruktif. Perubahan pribadi akan timbul jika terapis yang selaras bisa membangun hubungan dengan kliennya, suatu hubungan yang ditandai kehangatan, penerimaan, dan pengertian empatik yang akurat, konseling terapeutik berlandaskan hubungan akukamu atau hubungan pribadike-pribadi dalam keamanan dan penerimaan yang mendorong klien 


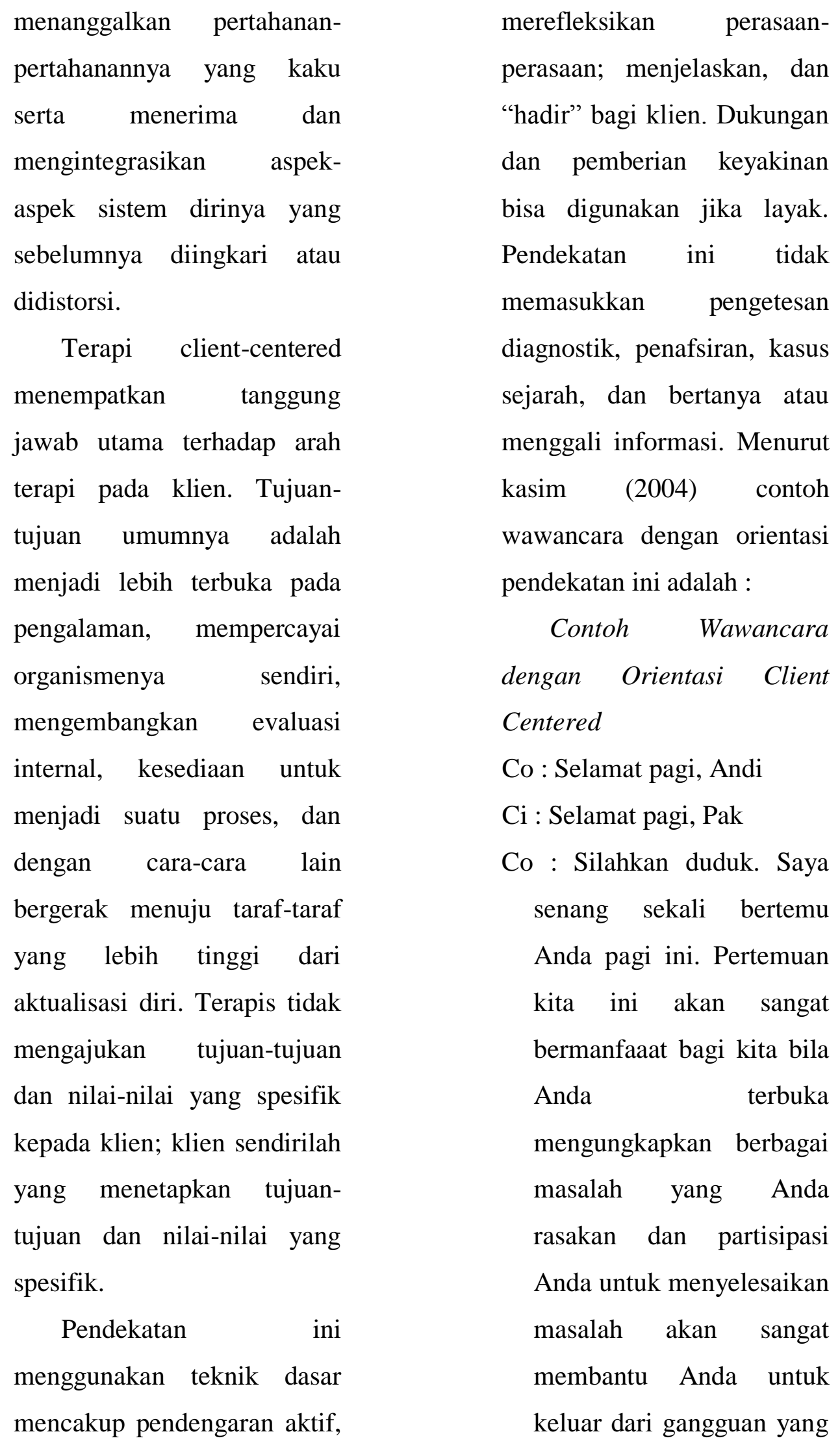


Anda alami. Nah, persoalah apa sebenarnya yang sedang Anda rasakan $?$

$\mathrm{Ci}$ : Saya merasa kecewa menghadapi kesulitan belajar yang telah saya hadapi dan takut kepada orangtua karena tidak memenuhi harapan mereka untuk menjadi ekonom menggantikan usaha bisnis ayah saya di masa depan.... Co : O.......Ya

$\mathrm{Ci}$ : saya adalah anak satusatunya laki-laki dari tiga bersaudara yang kelak menjadi tumpuan keluarga di bidang bisnis. Mereka merasa yakin saya akan berhasil karena tahun pertama saya telah memperlihatkan prestasi terbaik saya namun pada semester tiga ini prestasi saya menurun.

Co : Anda merasa tidak yakin pada semester tiga lalu untuk berprestasi dan Anda kecewa menghadapi kenyataan tersebut.
$\mathrm{Ci}$ :saya merasa yakin mempersiapkan diri untuk ujian tapi saya cemas sewaktu menghadapi ujian dan takut akan gagal karena tidak mampu menjawab semua soal matematika dan akuntansi sehingga....

Co: kecemasan Anda mengganggu konsentrasi Anda mengerjakan soalsoal hitungan sehingga hilang semua hal yang Anda telah pelajari

$\mathrm{Ci}$ : Ya, saya mengerjakan dengan sangat hati-hati takut salah dan tegang sehingga tidak selesai mengerjakan seluruh soal. Matematika kan tidak terlalu penting di ekonomi

Ci. : perasaan tegang dan cemas serta sikap negatif Andalah yang melumpuhkan potensi Anda

Co : ya saya memang tidak bisa matematika dan akuntansi 
$\mathrm{Ci}$ : itu berarti anda belum memahami dan menerima diri Anda sendiri

Co : jadi jalan keluarnya bagaimana pak ? nampaknya bapak selalu memojokkan saya

$\mathrm{Ci}$ : jalan keluarnya ada pada Anda sendiri. Bila persepsi dan sikap positif Anda berkembang, maka potensi Anda pun berkembang. Matematika Anda di SMU sebenarnya baik, bukan? Berbagai perbaikan prestasi dapat terjadi bila anda merubah diri Anda sendiri

Co : jadi bapak menantang saya untuk berubah?

$\mathrm{Ci}$ : bukan, Andalah yang harus menantang diri Anda untuk berkembang

\section{PENUTUP}

Pendekatan konseling yang menekankan pada keaktifan konseli untuk bereksplorasi mengungkapkan dirinya pada permasalahan yang dihadapinya. Arah bantuan konselor lebih menekankan pada pemahaman diri klien secara pribadi khususnya kesadaran akan perasaan terbanding permasalahannya. Peran konselor pada kondisi tersebut adalah sebagai "pendengar yang baik", "cermin diri bagi konseli", pemberi kemudahan bagi konseli untuk berinisiatif karena setiap kesadaran yang muncul akan memberi perubahan dan pengembangan diri dan berlanjut untuk mengaktualisasikan diri berdasarkan persepsi konseli sendiri.

\section{DAFTAR PUSTAKA}

Corey, Geral. 2006. Teori Dan Praktek Konseling Dan Psikoterapi(dialih bahasakan oleh E. Koswara). Bandung : PT. Refika Aditama.

Hidayat, Dede Rahmat. 2011. Teori Dan Aplikasi Psikologi Kepribadian Dalam Konseling. Bogor: Ghalia Indonesia.

Juntika. A. 2006. Bimbingan Konseling - Dalam Berbagai Latar Kehidupan. Bandung: PT. Refika Aditama.

Kasim, Anwar. 2004. Konseling Mikro (Pedoman Pengembangan Keterampilan Konseling Mikro). Universitas Negeri Jakarta.

Nelson, Richard. 2011. Teori dan Praktik Konseling dan Terapi. Edisi keempat. Yogyakarta: Pustaka Pelajar. 